\title{
THE APPEARANCE AND SIGNIFICANCE OF TISSUE MAST CELLS IN HUMAN BONE MARROW
}

\author{
BY \\ J. M. JOHNSTONE \\ From the Department of Pathology, the University and Western Infirmary, Glasgow
}

(RECEIVED FOR PUBLICATION MARCH 4, 1954)

Despite an increasingly vast literature concerning the examination of bone marrow, scant attention has been paid to the occurrence of tissue mast cells in human marrow or to their significance when present. Only recently have mast cells been described in the marrow of a small number of cases by Rohr (1949), Leitner (1948, 1949), Bremy (1950), Tischendorf and Hartmann (1950), Fadem (1951), Koszewski (1952), and Hayhoe (1953). Generally the patients had a severe marrow disturbance, which was frequently of the hypo- or aplastic variety, and, in the opinion of both Undritz (1946a and b) and Bremy (1950), the appearance of mast cells in the marrow indicates severe marrow depression and is of diagnostic and prognostic significance. However, Williams (1952), using marrow biopsy particle smears, was able to demonstrate mast cells in as many as $56(17 \%)$ of 325 marrows.

Fixed tissue sections of routine marrow aspirates were used in the present work, the object of which was to observe the frequency with which tissue mast cells occur in human marrow and to try to assess their significance.

\section{Methods and Materials}

The material for this investigation was taken from consecutive marrow aspirates submitted routinely to this laboratory for examination, the marrow samples being aspirated by standard methods, in most instances from the sternum. While sections of some of the earlier material were prepared according to the method described by Cappell, Hutchison, and Smith (1947), for the majority the modification detailed by Hutchison (1953) was used. The sections were stained with $0.001 \%$ aqueous toluidine blue, and while no difference was found to exist between the staining properties of mast cells in sections prepared by either method, the advantage of the latter lies in the fact that the blood, which always contaminates and dilutes aspirates, is removed in the processing and consequently a fragment of pure marrow concentrate is obtained.

Tissue mast cells and basophil leucocytes (blood mast cells) differ morphologically, having in common only the metachromatic staining property of their granules. As the granules of these latter cells have been found to be extremely soluble in water and alcohol they are not seen in fixed tissue sections when an aqueous or alcoholic fixative has been used, and the basophil leucocytes therefore cannot be identified.

Sections have been compared by enumerating the mast cells in microscopic fields at a constant magnification $(\times 320)$, and the marrows placed in one or other of the following groups. Those marrows in which no mast cells were seen form Group 1 : Group 2 contains marrows with an average of up to five mast cells per microscopic field, while in Group 3 an average of more than five mast cells was seen in each field. Only occasionally was it found difficult to decide into which group a marrow should be placed.

\section{Incidence}

Apart from necropsy material, which will be mentioned later, 269 marrow aspirates from 230 patients were examined. No mast cells were seen in $68(30 \%)$ patients (Group 1). Group 2 contained the largest number with 139 (60\%) cases, while the remaining $23(10 \%)$ fell into Group 3. The pathological diagnoses of the patients in each group are detailed in Table $\mathrm{I}$.

Twenty-seven patients had more than one marrow aspiration. In 21 the marrows were classified under the same group each time, in one case the proportion of mast cells remaining constant over 10 marrow examinations. In the remaining six patients the number of mast cells varied only slightly.

The advantage of sections over smears in the demonstration of tissue mast cells was striking. No quantitative comparison was made, but examining smears for their presence was time consuming and generally unrewarding. Even when shown to be abundant in the sections they were usually absent or scanty in the smears.

\section{Morphology}

The morphological characteristics of mast cells seen in marrow have been described elsewhere 


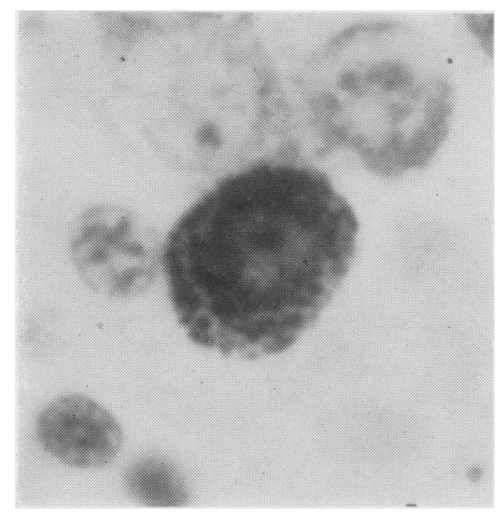

Fig. 1.-Details of two mast cells, one $(b)$ showing an elongated cytoplasmic process $\times 1,900$ (toluidine blue).

Fig. $1 a$

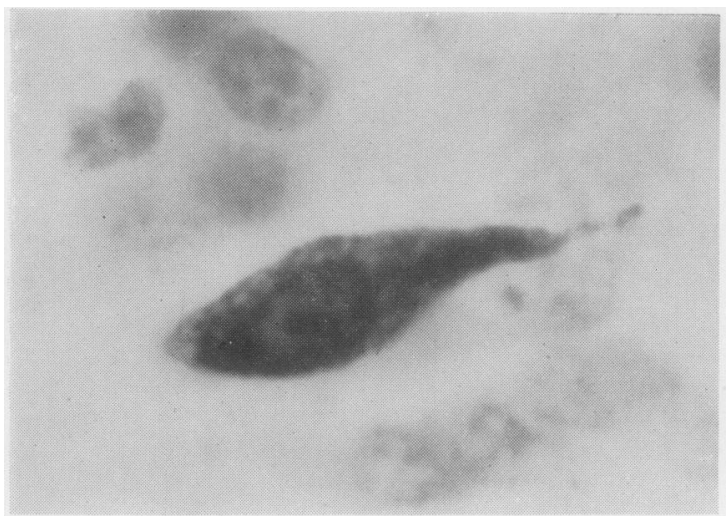

FIG. $1 b$

(Breny, 1950 ; Fadem, 1951). While the majority of the cells are rounded or ovoid (Fig. 1) bizarre forms are frequently seen. Some show pseudo- podia-like extensions, many are elongated and spindle-shaped, while others have a blunted head containing the nucleus with the remainder of the cytoplasm drawn out into a long filamentous process, occasionally seen to be bifid. Cytoplasmic granulations frequently overlaid the nucleus and often completely obscured it. Mitotic division and binucleated forms were not seen.

\section{Distribution}

Mast cells are known to occur throughout the body and particularly in relation to the adventitia of small blood vessels. This has certainly been observed in the marrow, but for the most part they are by no means confined to this situation. They occur somewhat irregularly ; in the reticular framework of the marrow, among the haemopoietic elements, and even stretched over the surface of fat cells. The irregularity of distribution is occasionally pronounced and a small area with abundant mast cells may be observed in a marrow which otherwise contains but few mast cells.

In sections of the whole thickness of bone obtained at necropsy the mast cells are often seen to be most numerous in and about the endosteum but scanty towards the centre of the medullary cavity. This was also noted by Ellis (1949) at the necropsy of a 12-month-old infant with urticaria pigmentosa.

\section{Age}

Very few children were included in this material, the majority of the patients being in the fifth to seventh decades, the ages ranging from 11 to 81 years.

TABLE I

TYPES OF CASES COMPRISING EACH GROUP

\begin{tabular}{|c|c|c|c|c|}
\hline Type of Case & & Group 1 : No Mast Cells & Group 2: Up to 5 Mast Cells per Field & $\begin{array}{l}\text { Group 3: More than } 5 \text { Mast } \\
\text { Cells per Field }\end{array}$ \\
\hline 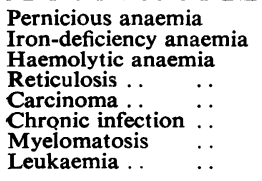 & $\begin{array}{l}\ldots \\
\cdots \\
\cdots \\
\cdots \\
\cdots \\
\cdots\end{array}$ & $\begin{array}{l}20 \\
12 \\
4 \\
3 \\
2 \\
3 \\
8\end{array}$ & $\begin{array}{r}38 \\
43 \\
3 \\
6 \\
10 \\
5 \\
2 \\
1\end{array}$ & $\begin{array}{l}6 \\
5 \\
\frac{1}{2} \\
\frac{2}{1}\end{array}$ \\
\hline Miscellaneous & $\cdots$ & $\begin{array}{l}\text { Polycythaemia, myxoedema }(2 \\
\text { each); aregenerative anaemia, } \\
\text { cerebro-vascular degeneration, } \\
\text { red cell aplasia, osteoporosis, } \\
\text { scurvy, anxiety state, nephritis, } \\
\text { mitral stenosis, histoplasmosis, } \\
\text { malabsorption syndrome, gastro- } \\
\text { enteritis, myeloid metaplasia (1 } \\
\text { each) }\end{array}$ & $\begin{array}{l}\text { 31 } \\
\text { Vascular disease (4), cirrhosis, Banti } \\
\text { syndrome, B.T. malaria, nephritis, } \\
\text { treated breast carcinoma (2 each); } \\
\text { aplastic anaemia, essential thrombo- } \\
\text { cytopenic purpura, normal, sprue, } \\
\text { pneumonia, splenic neutropenia, } \\
\text { sarcoidosis, ulcerative colitis, stea- } \\
\text { torrhoea, peripheral neuritis, dis- } \\
\text { seminated sclerosis, infectious } \\
\text { mononucleosis, haemachromatosis, } \\
\text { rheumatoid arthritis, renal cyst, } \\
\text { peptic ulcer, cardiac failure (1 each) }\end{array}$ & \begin{tabular}{l}
\multicolumn{1}{c}{8} \\
Aregenerative anaemia, unexplained \\
continued pyrexia, uraemia, Banti \\
syndrome, aplastic anaemia, osteo- \\
porosis, oesophageal stricture, \\
cachexia (1 each)
\end{tabular} \\
\hline Total & $\ldots$ & 68 & 139 & 23 \\
\hline
\end{tabular}




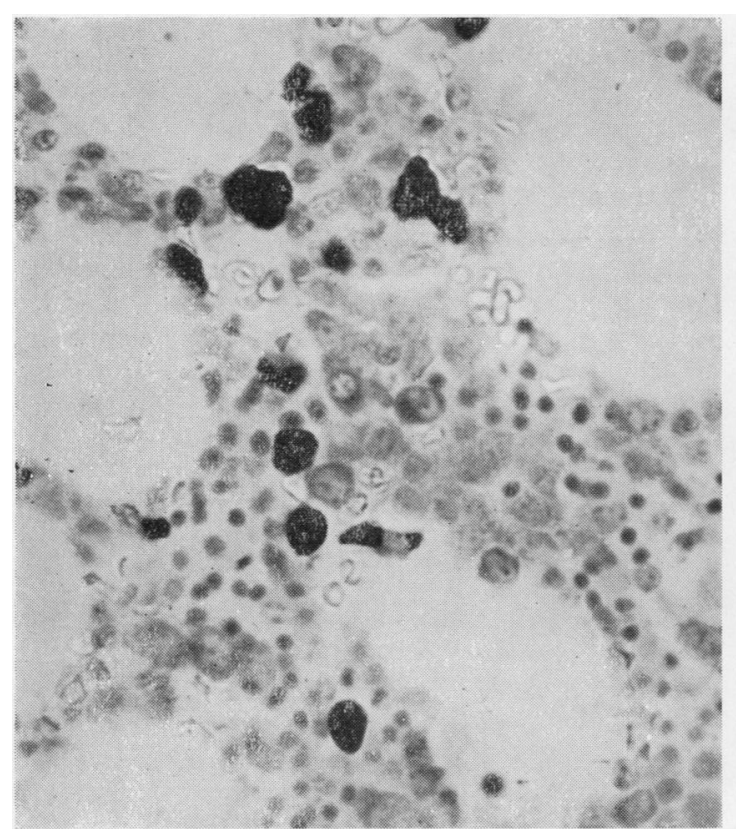

(a)

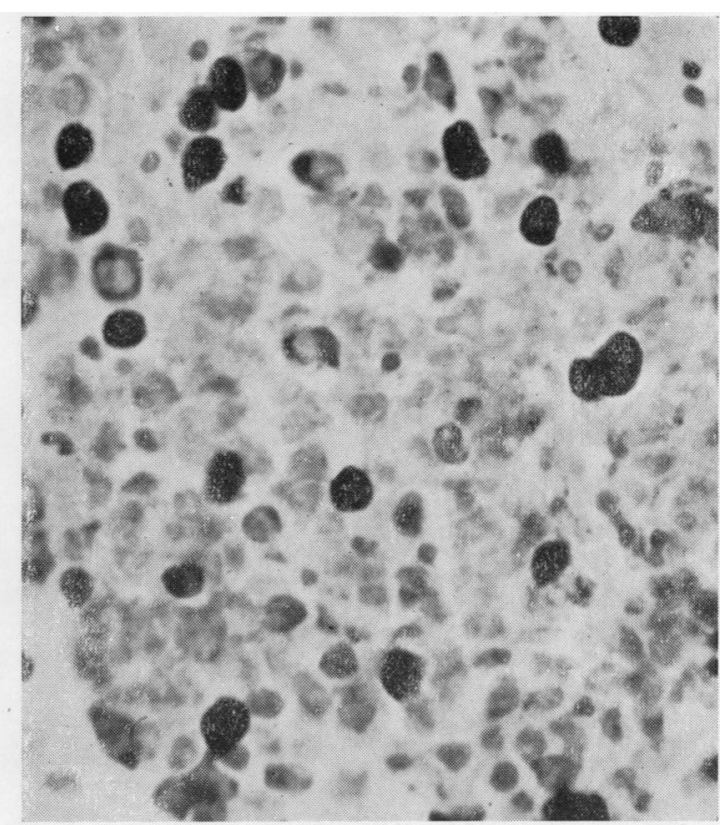

(b)

FIG. 2. - (a) Large numbers of tissue mast cells in a marrow of normal erythropoiesis $\times 750$ (toluidine blue). (b) Many tissue mast cells in a hyperplastic marrow (pernicious anaemia) $\times 650$ (toluidine blue).

Marrow was obtained at necropsy from various sites from 31 infants and children dying from a wide variety of pathological conditions. Mast cells were seen in only six cases and were always scanty.

\section{Iron}

Iron is stored in stainable form in the reticuloendothelial cells of the marrow in varying amounts dependent on the existing pathological conditions. Marrow sections from 185 of the aspirates had been stained for iron (Hutchison, 1953), but no correlation could be found between the iron content of the marrow and the number of mast cells seen.

\section{Haemopoiesis}

At an early stage in this investigation it seemed that the numbers of mast cells in the marrow might depend on a purely mechanical factor and be regu-

TABLE II

NUMBER OF CASES IN EACH GROUP COMPARED WITH THE DEGREE OF HAEMOPOIESIS

\begin{tabular}{|c|c|c|c|c|}
\hline \multirow{2}{*}{ Group } & \multicolumn{4}{|c|}{ Degree of Haemopoiesis } \\
\hline & Hypocellular & Normal & $\begin{array}{c}\text { Moderate } \\
\text { Hyperplasia }\end{array}$ & $\begin{array}{c}\text { Marked } \\
\text { Hyperplasia }\end{array}$ \\
\hline $\begin{array}{ll}\begin{array}{l}\text { One } \\
\text { Two }\end{array} \\
\text { Three }\end{array}$ & $\begin{array}{l}1 \\
3 \\
2\end{array}$ & $\begin{array}{r}18 \\
59 \\
7\end{array}$ & $\begin{array}{r}18 \\
44 \\
6\end{array}$ & $\begin{array}{r}31 \\
33 \\
8\end{array}$ \\
\hline
\end{tabular}

lated simply by the degree of marrow cellularity, i.e., extreme marrow hyperplasia might crowd out mast cells from the marrow and hypoplasia allow their free multiplication. That this is not the case is readily seen in Table II, where it is obvious that there is no association between the numbers of mast cells and the extent of haemopoiesis (Fig. 2).

\section{Lymph Follicles}

In sections from $21(9 \%)$ of the cases lymphoid follicles were observed in the marrow. These follicles are minute foci or aggregates of small lymphocytes with no germinal centre. Mast cells appear constantly in the periphery of these follicles, but are never observed in the centre (Fig. 3). The number of mast cells varied considerably; occasionally they were scanty, generally plentiful, and sometimes abundant. While constantly present in these lymphoid follicles, transitional forms between mast cells and lymphocytes were not observed, and the lymphocyte and plasma cell origin of mast cells expounded by Downey (1913) cannot be refuted or confirmed.

\section{Discussion}

It is our belief that tissue mast cells form a normal constituent of human bone marrow. By making use of fixed tissue sections, mast cells have 
been observed in as many as $70 \%$ of the marrows examined. The pathological state of the patients from which these marrows were aspirated represent a wide variety of conditions, but some of the marrows themselves show no qualitative abnormality. Further, mast cells have been demonstrated in marrow obtained at necropsy from a few normal healthy individuals who have died from injuries sustained in various forms of accidents.

Mast cells were not observed in $30 \%$ of the marrows, but it is probable that when scanty their presence or absence in any given marrow section may well be governed by the selection inevitable in a small sample.

In a small proportion of the present cases the numbers of observed mast cells must be considered abnormally high in relation to the numbers seen in the great majority of the marrows. The cause of this increase is not immediately apparent although several suggestions have been put forward. Mast cell granules are generally believed to contain heparin (Jorpes, Holmgren, and Wilander, 1937 ; Jorpes, 1946 ; Oliver, Bloom and Mangieri, 1947 ; Köksal, 1953), and Paff, Bloom, and Reilly (1947) thought that the inhibitory effect of heparin on growth (Goerner, 1931) explained the failure of all cells but mast cells to grow when tissue from dog mastocytoma was cultured, but Macdougall and Riley (1954) attribute this simply to the great preponderance of mast cells present in the original tissue. Fadem (1951) considered it possible that a similar relationship might exist between mast

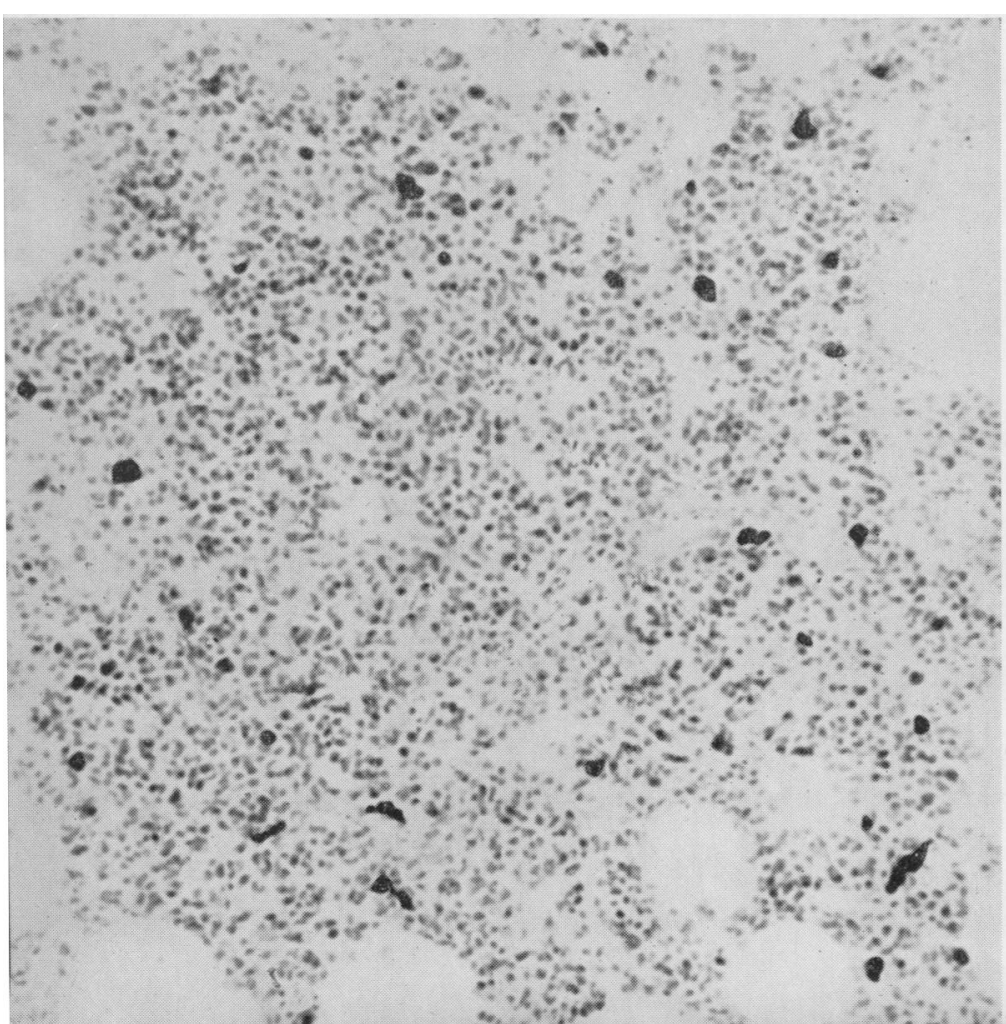

cell accumulation and hypoplasia of the marrow in some cases, the marrow growth being inhibited by the excessive amount of heparin elaborated by the increased numbers of mast cells in the marrow. However, if this be the case, the marrow depression is but secondary to the increase of mast cells and the explanation of this increase remains unsolved.

In the present series marrow hypoplasia was observed in only two of the aspirates showing mast cell accumulation, erythropoiesis in the remainder being either normal or hyperplastic. Further, in addition to the six cases of severe marrow depression included in Table I, material from marrow depressive states from eight necropsies and two bone marrow trephines was examined, mast cell accumulation being observed in only five of these 16 cases. From this it is clear that hypoplasia of the marrow per se is neither a prerequisite for mast cell accumulation nor an inevitable consequence of it, although the presence of mast cells is frequently associated with some form of marrow depression in the cases recorded in the literature (Bremy, 1950 ; Leitner, 1949 ; Rohr, 1949 ; Fadem, 1951 ; Hayhoe, 1953).

Describing "myelitis chronica interstitialis" Rohr (1948) suggested that in the early stages of the more serious form there is an irreversible proliferation of the marrow stromal fibrocytes and reticulum cells together with plasma cells and mast cells, sometimes leading to a resistant secondary marrow depression, and later to the final extreme picture of myelofibrosis. The marrow stromal change was thought to be the local manifestation of a systemic reaction, possibly of an allergic nature, to some infection or noxious agent. Certainly mast cells are known to accumulate in other sites in relation to areas of chronic inflammation, and it is interesting to note that recent work affords strong presumptive evidence that the granules of mast cells contain histamine in addition to heparin (Riley and West, 1952; Riley, 1953). Thus their association with anaphylactic-allergic states would not be unexpected.

Brief details of all the present cases showing mast cell accumulation are given in the table in the appendix. While this table contains a few cases of marrow depressive states similar to those described by Rohr $(1948,1949)$ and Bremy (1950), on the whole it affords little evidence to support their view that the appearance of

Fig. 3.-Lymphoid follicle in marrow with many tissue mast cells towards the periphery $\times 225$ (tohidine blue). 
mast cells in the marrow is part of a reaction to an allergic process. There is little in the cases which might suggest any infective agent, either past or present, and the majority of the marrows are hyperplastic with no increase in the amount of stromal elements or plasma cells.

Anaemia of moderate to severe degree is the only factor common to all the cases although many do also show some degree of splenomegaly. But neither anaemia nor splenomegaly, alone or in combination, are essential for, or invariably accompanied by, mast cell proliferation.

Adrenal cortical hypofunction or adrenalectomy is said to result in marrow hypoplasia (Gordon and Charipper, 1947 ; Feldman, Rachmilewitz, Stein, and Stein, 1953), and the number of mast cells in the skin, muscle, and heart of intact rats was observed by Cavallero and Braccini (1951) to be markedly reduced following the injection of cortisone, but the effect of adrenalectomy on these cells is not known. It seems therefore theoretically possible that adrenal cortical hypofunction may be at least partly responsible for the increase of mast cells in the marrow of some cases exhibiting marrow depression, but the response to A.C.T.H. and cortisone in such patients is as yet most disappointing (Wintrobe, 1951 ; Spaet, Rosenthal, and Dameshek, 1951 ; Davidson, Girdwood, and Swan, 1952 ; Medical Research Council Report, 1953), and no change was observed in the number of mast cells in the marrow of two cases receiving treatment with A.C.T.H. (Williams, 1952).

\section{Summary and Conclusions}

Two hundred and sixty-nine marrow aspirates from 230 patients have been specifically examined for mast cells and they have been classified in three grades according to the numbers present. The advantage of section over smears for this purpose is stressed.

No mast cells were seen in $68(30 \%)$ of the patients, a few were present in $139(60 \%)$, and in $23(10 \%)$ they were abundant.

The presence and numbers of mast cells in the marrow bore no relation to the iron content of the marrow or to the degree of erythropoiesis.

Lymph follicles were seen in $21(9 \%)$ of the marrows and mast cells were then constantly observed in their periphery; they were, however, not confined to this situation. The morphology and distribution of the mast cells have been described.

Mast cells are believed to form one of the normal constituents of human bone marrow and they have been observed to accumulate abnormally in a small proportion of cases. The cause of this increase is not clear and no single factor can as yet be held responsible. While these cases show a varying degree of anaemia associated generally with a moderate to severe marrow disturbance, the earlier explanations offered and the gloomy prognosis previously associated with the appearance of mast cells in the marrow cannot be substantiated.

I should like to thank the physicians and surgeons in charge of wards at the Western Infirmary for the clinical details, Mr. M. Fitch, F.I.M.L.T., for technical assistance, and Mr. G. Kerr for the photomicrographs.

\section{REFERENCES}

Bremy, P. (1950). Die Gewebsmastzellen im menschlichen Knochenmark. Thieme, Stuttgart.

Cappell, D. F., Hutchison, H. E., and Smith, G. H. (1947). Brit med. J., 1, 403.

Cavallero, Ċ., and Braccini, C. (1951). Proc. Soc. exp. Biol., N.Y. 78,141 .

Davidson, L. S. P., Girdwood, R. H., and Swan, H. T. (1952). Brit. med. J., 2, 1059

Downey, H. (1913), Folia haemat., Lpz. (Arch.), 16, 49.

Ellis, J. M. (1949). Arch. Path., Chicago, 48, 426.

Fadem, R. S. (1951). Blood, 6, 614.

Feldman, J. D., Rachmilewitz, M., Stein, O., and Stein, Y. (1953). Ibid., 8, 342 .

Goerner, A. (1931). J. Lab. clin. Med., 16, 369.

Gordon, A. S., and Charipper, H. A. (1947). Ann. N.Y. Acad. Sci. 48,615 .

Hayhoe, F. G. J. (1953). Brit. med. J., 1, 1143.

Hutchison, H. E. (1953). Blood, 8, 236.

Jorpes, E., Holmgren, H., and Wilander, O. (1937). Z. mikr.-anat. Forsch., 42, 279. Jorres, J. F. (1946). Heparin in the Treatment of Thrombosis, 2nd ed.
Oxford Medical Publications, London.

Köksal, M. (1953). Nature, Lond., 172, 733.

Koszewski, B. J. (1952). Blood, 7, 1182.

Leitner, S. J. (1948). Acta med. scand., 130, 66.

Leitner, S. J. (1948). Acta med. scand., 130, 66.

Macdougali, J. D. B., and Riley, J. F. (1954). Proceedings of the Scottish Society for Experimental Medicine, Glasgow, 6 February, 1954.

Medical Research Council Haematology Panel's Second Report (1953). Brit. med. J., 2, 1400.

Oliver, J., Bloom, F., and Mangieri, C. (1947). J. exp. Med., 86, 107

Paff, G. H., Bloom, F., and Reilly, C. (1947). Ibid., 86, 117.

Riley, J. F. (1953). J. Path. Bact., 65, 471.

$\longrightarrow$ and West, G. B. (1952). J. Physiol., Lond., 117, 72P.

Rohr, K. (1948). Sang, 19, 521.

- (1949). Blood, 4, 130.

Spaet, T. H., Rosenthal, M. C., and Dameshek, W. (1951), Bull. New Engl. med. Cent., 13, 252.

Tischendorf, W., and Hartmann, F. (1950). Acta haemat., Basel, 4, 374.

Undritz, E. (1946a). Schweiz. med. Wschr., 76, 88 and 115.

Will (1946b). Ibid., 76, 333.

Williams, G. T. (1952). Amer. J. clin. Path., 22, 1039.

Wintrobe, M. M. (1951). Clinical Haematolog.v. 3rd ed. Kimpton, London. 
A P P E N D I X

BRIEF DETAILS OF ALL CASES SHOWING MAST CELL PROLIFERATION

\begin{tabular}{|c|c|c|c|c|c|c|c|c|}
\hline $\begin{array}{l}\text { Case } \\
\text { No. }\end{array}$ & Age & Sex & $\begin{array}{c}\mathrm{Hb} \\
(\mathrm{g} . \%)\end{array}$ & $\underset{\text { (m. C.mm.) }}{\text { R.B.C. }}$ & \multicolumn{2}{|c|}{ Erythropoiesis } & Diagnosis & Remarks \\
\hline 1 & 50 & $\mathbf{M}$ & $10 \cdot 5$ & 335 & Hyperplasia & + & $\begin{array}{l}\text { Bronchial carcinoma; } \\
\text { skeletal metastases; } \\
\text { specific aortitis }\end{array}$ & Wassermann reaction positive \\
\hline 2 & $\begin{array}{l}72 \\
48\end{array}$ & $\underset{\mathrm{M}}{\mathrm{M}}$ & $\begin{array}{l}5 \cdot 7 \\
8 \cdot 3\end{array}$ & $\begin{array}{l}1.60 \\
1.95\end{array}$ & , & $++t$ & Pernicious anaemia & Megaloblastic marrow \\
\hline $\begin{array}{l}3 \\
4\end{array}$ & $\begin{array}{l}48 \\
69\end{array}$ & $\stackrel{F}{F}$ & $\begin{array}{l}8 \cdot 3 \\
3 \cdot 0\end{array}$ & $\begin{array}{l}1.95 \\
0.99\end{array}$ & & $\begin{array}{l}+t+ \\
t+\end{array}$ & ", $\quad "$, & $\dddot{\eta} \quad \dddot{\eta}$ \\
\hline 5 & 50 & $\mathbf{M}$ & $4 \cdot 0$ & 1.05 & \multicolumn{2}{|c|}{ Severe hypoplasia } & Aplastic & $\begin{array}{l}\text { Death in } 412 \text { from first symptom: no cause } \\
\text { identified: few cells, other than lymphocytes, } \\
\text { in marrow }\end{array}$ \\
\hline 6 & 62 & $\mathrm{~F}$ & $9 \cdot 7$ & $3 \cdot 12$ & \multicolumn{2}{|l|}{ Normal } & $\begin{array}{l}\text { Atypical rheumatoid } \\
\text { arthritis }\end{array}$ & $\begin{array}{l}\text { Mild pyrexia; joint pains; W.B.C. } 8,000 \text {; labora- } \\
\text { tory tests negative; responded eventually to } \\
\text { Butazolidin }\end{array}$ \\
\hline $\begin{array}{l}7 \\
8\end{array}$ & $\begin{array}{l}56 \\
56\end{array}$ & $\mathbf{F}$ & $\begin{array}{l}6 \cdot 0 \\
7 \cdot 0\end{array}$ & $\begin{array}{l}1.40 \\
1.41\end{array}$ & Hyperplasia & $\begin{array}{l}++t \\
++t\end{array}$ & Pernicious anaemia & Megaloblastic marrow \\
\hline 9 & $\ddot{40}$ & $\vec{F}$ & 6.0 & $\begin{array}{l}1.41 \\
3.55\end{array}$ & , & $\begin{array}{l}+++ \\
++\end{array}$ & Iron-deficiency anaemia & " $\quad$ " \\
\hline 10 & 66 & $\mathbf{M}$ & 60 & 1.98 & \multicolumn{2}{|c|}{ Normal } & Carcinomatosis & $\begin{array}{l}\text { Carcinomatosis; hepatic secondaries proven a } \\
\text { laparatomy? Bronchial primary. No necropsy }\end{array}$ \\
\hline 11 & 53 & $\mathbf{M}$ & $10 \cdot 0$ & 3.90 & \multicolumn{2}{|l|}{ " } & Cachexia & $\begin{array}{l}\text { 6/12 weakness and weight loss: E.S.R. } 108 / 121 ; \\
\text { hepatomegaly; achlorhydria; skeleton } \\
\text { normal; piasma proteins normal; G.I. tract } \\
\text { normal; pyrexia responded to antibiotics }\end{array}$ \\
\hline $\begin{array}{l}12 \\
13\end{array}$ & $\begin{array}{l}53 \\
44\end{array}$ & $\stackrel{\mathbf{M}}{\mathbf{F}}$ & $\begin{array}{l}5 \cdot 9 \\
6 \cdot 1\end{array}$ & $\begin{array}{l}1.03 \\
1.72\end{array}$ & $\begin{array}{c}\text { Hyperplasia } \\
\text { ", }\end{array}$ & $\begin{array}{l}+++ \\
+++\end{array}$ & $\begin{array}{l}\text { Pernicious anaemia } \\
\text { Aregenerative anaemia }\end{array}$ & $\begin{array}{l}\text { Megaloblastic marrow } \\
\text { W.B.C. } 2,900 \text { c.mm.; marrow-megakaryocytes } \\
++ \text {; scanty erythroid series; maturation } \\
\text { failure of both erythroid and myeloid series; } \\
\text { no stromal or plasma cell increase. Required } \\
\text { blood transfusions every } 652\end{array}$ \\
\hline $\begin{array}{l}14 \\
15\end{array}$ & $\begin{array}{l}65 \\
56\end{array}$ & F & $9 \cdot 0$ & $\stackrel{2 \cdot 4}{-}$ & Normäl & ++ & $\begin{array}{l}\text { Oesophageal stricture } \\
\text { Osteoporosis }\end{array}$ & $\begin{array}{l}\text { Simple oesophageal ulceration. W.R. neg. } \\
\text { Epileptic. Long-standing generalized osteo- } \\
\text { porosis with multiple fractures and collapse of } \\
\text { several lumbar vertebrae }\end{array}$ \\
\hline 16 & 50 & $\mathbf{M}$ & $9 \cdot 7$ & $3 \cdot 3$ & Hyperplasia & $\div+$ & $\begin{array}{l}\text { Aleukaemic lymphatic } \\
\text { leukaemia }\end{array}$ & Confirmed at necropsy \\
\hline 17 & 52 & $\mathbf{F}$ & $8 \cdot 0$ & $4 \cdot 2$ & , & ++ & Banti's syndrome & $\begin{array}{l}\text { Iron deficient; W.B.C. } 2,600 \text { : splenomegaly; } \\
\text { thymol turbidity } 6 \text { units; plasma proteins } \\
\text { normal. Several hundred mast cel!s/field }\end{array}$ \\
\hline $\begin{array}{l}18 \\
19\end{array}$ & $\begin{array}{l}46 \\
62\end{array}$ & $\begin{array}{l}\mathbf{F} \\
\mathbf{M}\end{array}$ & $\begin{array}{l}5 \cdot 6 \\
4 \cdot 5\end{array}$ & $\begin{array}{l}3 \cdot 2 \\
2 \cdot 9\end{array}$ & , & + & Iron-deficiency anaemia & - \\
\hline 20 & 81 & $\mathbf{M}$ & $9 \cdot 0$ & $3 \cdot 0$ & & Üraemia " & $\begin{array}{l}\text { Hypertensive. Prostatic obstruction; blood urea } \\
174 \mathrm{mg} . \% \text { Plasma proteins normal }\end{array}$ \\
\hline $\begin{array}{l}21 \\
22\end{array}$ & $\begin{array}{l}26 \\
64\end{array}$ & F & $\begin{array}{r}5 \cdot 3 \\
10 \cdot 3\end{array}$ & $\begin{array}{l}3 \cdot 1 \\
4 \cdot 35\end{array}$ & \multicolumn{2}{|c|}{$\begin{array}{l}\text { Hyperplasia }+++ \\
\text { Norma! }\end{array}$} & $\begin{array}{l}\text { Iron-deficiency anaemia } \\
\text { P.U.O. }\end{array}$ & $\begin{array}{l}\text { Unexplained pyrexia for } 4 \text { months. Albumin } \\
3.1 \text {; globulin } 3.4 \text { g. } 100 \mathrm{ml} \text {. serum. E.S.R. } \\
120 \mathrm{~mm} \text {. in } 1 \text { hour. W.B.C. } 11,000 / \text { c.mm. } \\
\text { Normal differential. All other clinica! and } \\
\text { laboratory findings normal }\end{array}$ \\
\hline \multirow{2}{*}{\multicolumn{7}{|c|}{ Hyperplasia +++}} & Iron-deficiency anaemia & \\
\hline & & & & & & & & \\
\hline $\begin{array}{l}\text { Necrop } \\
25\end{array}$ & $\begin{array}{l}m a t c \\
44\end{array}$ & $\stackrel{i a l}{\mathrm{M}}$ & - & - & \multicolumn{2}{|l|}{ Hyponlasia } & Myelofibrosis & $\begin{array}{l}\text { Aplastic anaemia requiring transfusions for } 11 \\
\text { years; hepatomegaly and splenomegaly; at } \\
\text { necropsy, myelofibrosis and osteoscleros:s }\end{array}$ \\
\hline 26 & 67 & $\mathbf{F}$ & - & - & Normal & & Agranulocytosis & $\begin{array}{l}\text { Drug agranulocytosis: W.B.C. } 50 \text { c.mm. Ulcer- } \\
\text { ation of fauces and rectum: death from } \\
\text { pulmonary embolism }\end{array}$ \\
\hline 27 & 56 & $\mathbf{M}$ & 一 & - & Normal & & Aregenerative anaemia & No details available \\
\hline
\end{tabular}

